Hydrology and Earth System Sciences, 6(6), 959-970 (2002) C EGS

\title{
Assessment of terrigenous organic carbon input to the total organic carbon in sediments from Scottish transitional waters (sea lochs): methodology and preliminary results
}

\author{
P.S. Loh $^{3}$, A.D. Reeves ${ }^{1}$, J. Overnell ${ }^{2}$, S.M. Harvey ${ }^{2}$ and A.E.J. Miller ${ }^{3}$ \\ ${ }^{1}$ Geography Department, University of Dundee, Dundee, DD1 4HN, Scotland \\ ${ }^{2}$ SAMS, Dunstaffnage Marine Laboratory, Oban, PA37 1QA, Scotland \\ ${ }^{3}$ UHI Millennium Institute, SAMS, Dunstaffnage Marine Laboratory,Oban, PA37 1QA, Scotland
}

Email for corresponding author: a.d.reeves@dundee.ac.uk

\begin{abstract}
This paper addresses the assessment of terrestrially derived organic carbon in sediments from two Scottish sea lochs. The results illustrate a smooth decrease in area-specific sediment oxygen uptake rates along a transect of six stations from the head of Loch Creran to the sea, from $18.7 \mathrm{mmol} \mathrm{O}_{2} \mathrm{~m}^{-2} \mathrm{~d}^{-1}$ to $6.6 \mathrm{mmol} \mathrm{O}_{2} \mathrm{~m}^{-2} \mathrm{~d}^{-1}$. Measurement of the losses on ignition at two temperatures $\left(250^{\circ} \mathrm{C}\right.$ and $\left.500^{\circ} \mathrm{C}\right)$ of the sediment fraction from $1-2 \mathrm{~cm}$ depth at the same stations enabled the proportion of weight loss that occurred over the high temperature range to be calculated. These show a smooth increase from 0.33 to 0.62 . These observations indicate that (a) the amount of easily biodegradable organic material in the sediment decreases by two-thirds along the transect and (b) the proportion of refractory organic material in the sediment increases along the same transect. This suggests strongly that terrigenous organic material, brought down by the River Creran is a very important fuel for sediment diagenetic processes in this system. Preliminary analyses of the lignin composition of the same sediments indicate the predominance of non-woody gymnosperm tissue. Lignin is used as a proxy for terrigenous allochthonous material. Comparative data for Loch Etive are also presented.
\end{abstract}

Keywords: sedimentary organic carbon, Loch Creran, Loch Etive, oxygen uptake, lignin analysis

\section{Introduction}

Sea lochs are representative of low energy hydrographic regimes and act as traps for sediment which accumulates at relatively high rates. The sediments are rich in terrigenous organic matter. It is commonly considered that marinederived organic carbon is readily degradable whereas terrestrially-derived organic carbon is refractory, eventually becoming integrated into permanent sedimentary deposits. Thus, terrigenous particulate organic carbon which does not settle to the loch bed is transported seawards out of the loch, across the shelf and deposited on the shelf slope.

Organic material deposited in sediments is subject to bacterially mediated degradation, initially by heterotrophic bacteria which produce extracellular low molecular weight products. Other bacteria, using a variety of electron acceptors such as sulphate, nitrate, manganese (IV) and oxygen, then oxidise these. Except in euxinic conditions and under conditions of very high sedimentation, biological mixing eventually brings almost all the reduced intermediates such as sulphide, nitrite and manganese (II) to the surface where they are then oxidised. Thus, measurement of the rate of consumption of oxygen by intact sediment cores under ambient conditions is a good first approximation of the total rate of degradation (Jørgensen, 1982), accounting for 90 to $97 \%$ of total degradation.

Organic material entering the sediment of a sea loch may be autochthonous (derived from in situ production in the water column above) or allochthonous (derived from 
elsewhere). The autochthonous material is mainly in the form of either sedimented phytoplankton or zooplankton faecal pellets. In either case, it is relatively fresh and is believed to be degraded easily. In contrast, the allochthonous material is derived from the land and is often severely degraded and may in fact be thousands of years old before it reaches the sediment (Raymond and Bauer, 2001). The sediment microbial population degrades organic matter rich in algal remains more readily than organic matter derived from vascular plant material (Lyons and Gaudette, 1979). Thus, it has been commonly assumed that terrigenous organic material has little influence on rates of mineralisation in sea loch or estuary sediments. However, Eisma et al. (1985) found that about half of the riverine particulate organic carbon in the Gironde Estuary was decomposed at the freshwater/saltwater interface and Overnell et al. (1996) found that the highest rates of oxygen uptake in the upper basins of four Scottish sea lochs occurred at the heads (where the main freshwater inputs are situated). This phenomon was explored futher to evaluate the importance of terrigenous organic material to remineralisation rates in Scottish sea lochs. Preliminary results are reported here on the oxygen uptake rates and lignin analyses in sediment cores sampled from Lochs Creran and Etive. Lignin is used as a proxy for terrigenous allochthonous material. From the correlation of oxygen uptake and lignin concentrations in sediments, a measure of the importance of terrigenous material to benthic processes is derived (see Reeves and Preston, 1989 and 1991).

Plant tissues are the largest contributors of fixed carbon in the biosphere and also comprise the largest fraction of dead organic matter (Cain, 1980). Organic matter of terrestrial origin is derived largely from vascular plants (Moran et al., 1991). It is possible to identify land-derived organic matter through the analysis of the alkaline, cupric oxide oxidation products of lignin. Lignins are complex macromolecules present only in the cell walls of vascular plants and are resistant to degradation which makes them well suited for use as molecular input markers (Hedges and Ertel, 1982).

'Lignin' is derived from the Latin word lignum meaning wood (Sarkanen and Ludwig, 1971). It is one of the three main components in woody tissue which consists of cellulose, hemicellulose and lignin. Besides being an essential component of the woody stems of aborescent gymnosperms (conifers) and angiosperms (flowering plants), lignins are found as integral cell wall constituents in the stems, foliage and roots. Within the cells, lignin plays an important role in the transport of water, nutrients and metabolites by decreasing water permeation across the cell walls, imparting rigidity to the cell walls and also reducing the penetration of destructive enzymes, thus slowing the breakdown by micro-organisms (Goring, 1971). The structure of a model lignin molecule is illustrated in Fig. 1.

Lignins can be classified into three distinct groups based on their alkaline copper oxide oxidation products (Higuchi, 1980). The Syringyl phenols (S), i.e. syringaldehyde, acetosyringone and syringic acid, are representative of woody and non-woody angiosperms. The Cinnamyl phenols (C), i.e. p-coumaric and ferulic acids, are found in nonwoody angiosperms and all gymnosperms. Lastly, the Vanillyl phenols (V), i.e. vanillin, acetovanillone and vanillic acid, indicate gymnosperm tissues (Bianchi and Argyrou, 1997). Two useful parameters are the $S / V$ and $C / V$ ratios, the former representing lignin from angiosperms versus gymnosperms, the latter ratio giving information about lignin sources (woody $v$. nonwoody; Goni et al., 1998).

Microfungi and bacteria participate in the rapid aerobic degradation of lignin (Haider and Trojanowski, 1980). The micro-organisms that play a significant role in lignin

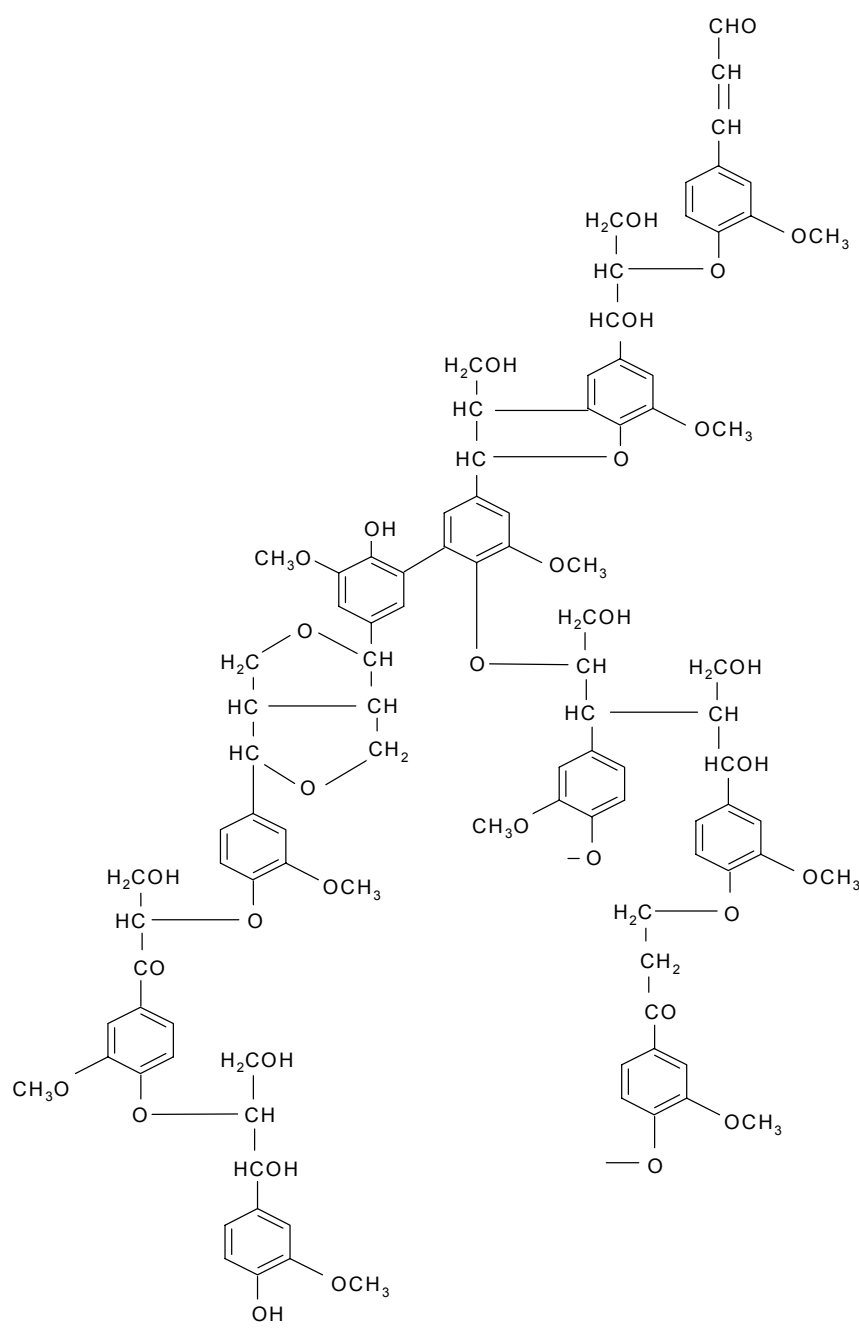

Fig. 1. Lignin structure (Libes, 1992) 
degradation are the white rot fungi from the family Hymenomycetes (Chang et al., 1980), actinomycetes (filamentous bacteria) and nonfilamentous eubacteria (e.g. Pseudomonas, Acinetobacter and Bacillus; Crawford et al., 1980).

Anaerobic degradation of lignin is extremely slow in comparison. This is because lignin degradation requires other substrates such as glucose as well as the inability of lignin to serve as an energy source and the increased recalcitrance of lignin during humification (Martin and Haider, 1980). In the absence of significant anaerobic decomposition of lignin, lignin and lignin-derived materials accumulate gradually forming the basis of brown coal and peat deposits (Young and Frazer, 1987; see Fig. 2).

Lignins are extremely stable in the sedimentary anaerobic environment; thus knowledge of lignin concentrations in sediments permits the derivation of palaeoecologic information which cannot be obtained through study of total organic carbon concentrations (Bader, 1956; Hedges and Ertel, 1982).

\section{Methodology}

\section{STUDY AREAS}

The two study areas are Loch Creran and Loch Etive, both situated on the west coast of Scotland (see Fig. 3.1). Sea lochs represent 'enclosed' zones or restricted exchange environments that provide unique ecosystems. Like other transitional waters, sea lochs are zones between land and open ocean, with freshwater entering at the head of the loch and saline water flowing in at the mouth (Watts, 1997). Sediment cores were collected from Loch Etive from January to March, 2001and at Loch Creran from May to September, 2001. Cores were collected using the Seol Mara, the Scottish Association for Marine Science vessel (10 m) equipped with a winch, hydraulic A-frame and a flat afterdeck, as well as the usual navigational aids.

\section{Loch Etive}

Loch Etive is approximately $28 \mathrm{~km}$ long from its head to the Falls of Lora at Connel and approximately $1 \mathrm{~km}$ across at its widest point. The Rivers Etive and Awe (at Bonawe)

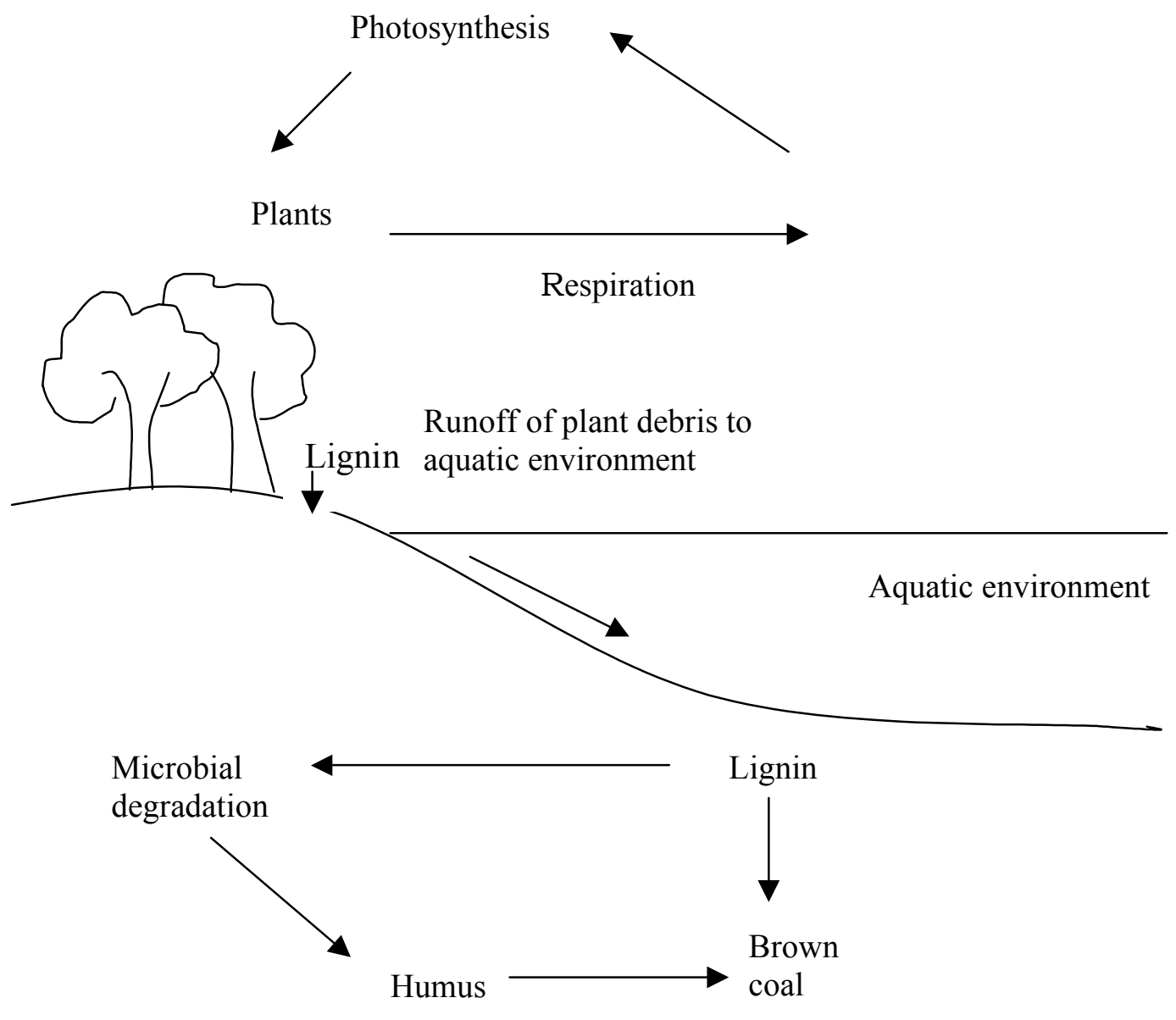

Fig. 2. The lignin cycle. Adapted from Christman and Oglesby, (1971) and Kirk et al., (1980) 


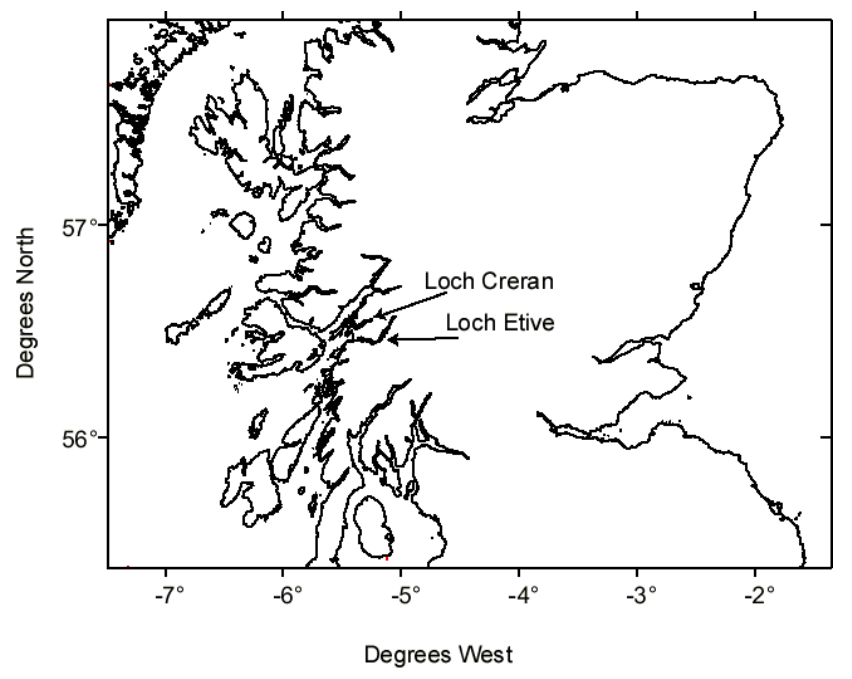

Fig. 3.1. Location map

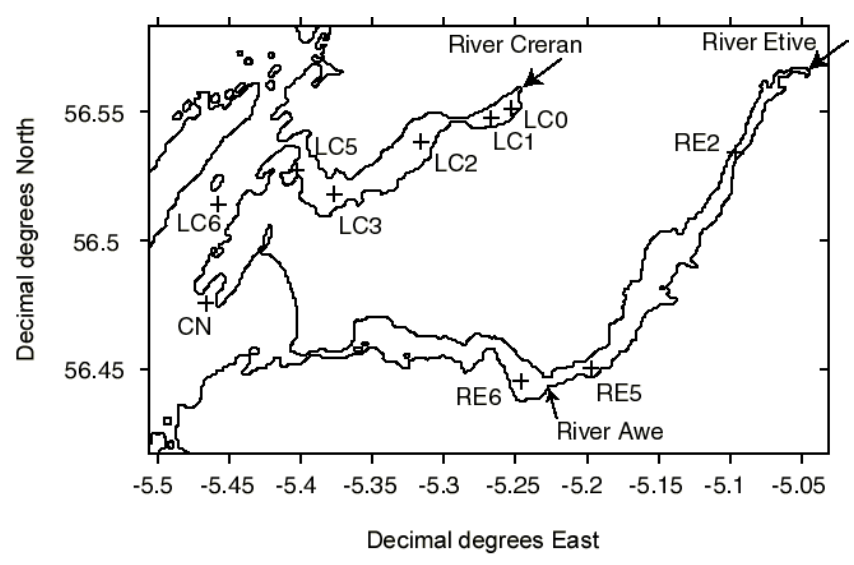

Fig. 3.2. Loch Etive and Loch Creran sample sites

are the two main fresh water inputs. Figure 3.2 shows the sampling sites along the loch. An additional sampling location is situated outside the loch in the Firth of Lorn (Camas Nathais). A full description of Loch Etive can be found in Edwards and Sharples (1991).

\section{Loch Creran}

A description of Loch Creran is also given by Edwards and Sharples (1991). It is approximately $14 \mathrm{~km}$ long and $1 \mathrm{~km}$ wide at its widest point (Fig. 3.2). The main freshwater input is from River Creran at the head of the upper basin: see Table 1 for all sample site coordinates and depths.

\section{SAMPLE COLLECTION AND TREATMENT}

Sediment samples were collected from Loch Etive and Loch Creran using a Craib corer (Craib, 1965) lined with an acrylic core tube $(24 \mathrm{~cm}$ long $\times 5.9 \mathrm{~cm}$ i.d). This corer returns
Table 1. Sampling station positions and depths

\begin{tabular}{lccc}
\hline & Lat. $(N)$ & Long. $(W)$ & Depth $(m)$ \\
\hline Loch CRERAN & & & \\
LC0 & 5633.0 & 0515.3 & 15 \\
LC1 & 5632.9 & 0516.1 & 38 \\
LC2 & 5632.1 & 0519.0 & 17 \\
LC3 & 5631.1 & 0522.6 & 45 \\
LC5 & 5631.7 & 0524.1 & 13 \\
LC6 & 5630.9 & 0527.4 & 48 \\
LoCH ETIVE & & & \\
RE2 & 5631.7 & 0506.0 & 40 \\
RE5 & 5627.3 & 0511.2 & 145 \\
RE6 & 5626.9 & 0514.8 & 60 \\
Camas Nathais & 5628.5 & 0528.1 & 20
\end{tabular}

cores with an undisturbed sediment-water interface. The cores when retrieved from the corer are approximately half full of sediment and half full of overlying water. Cores for lignin analysis were sliced ( $1 \mathrm{~cm}$ thickness) and kept in the freezer before freeze-drying. All glassware and reaction vessels used in the experiment were soaked overnight in $5 \%$ Decon, rinsed thoroughly and dried at $60^{\circ} \mathrm{C}$. The diethyl ether used in the lignin analysis was pre-treated with ammonium ferrous sulphate $\left(\mathrm{NH}_{4}\right)_{2} \mathrm{Fe}\left(\mathrm{SO}_{4}\right)_{2} \cdot 6 \mathrm{H}_{2} \mathrm{O}$ which acts as oxygen scavenger (Hedges and Ertel, 1982; Reeves and Preston, 1989).

\section{Analytical Methods}

\section{CUPRIC OXIDE OXIDATION}

The method for cupric oxide oxidation of sediment samples has been adapted from the following: Hedges and Ertel (1982); Ertel and Hedges (1984); Readman et al. (1986); Goni and Hedges (1990, 1992 and 1995); Gough et al. (1993); Opsahl and Benner (1993 and 1995) and Reeves and Preston (1991).

Approximately $0.5 \mathrm{~g}$ of the freeze-dried sediment sample was weighed into a PTFE-lined bomb with $1.0 \mathrm{~g} \mathrm{CuO} .7 \mathrm{~cm}^{3}$ of $8 \% \mathrm{w} /$ vol aqueous $\mathrm{NaOH} / \mathrm{H}_{2} \mathrm{O}$ was bubbled with nitrogen gas for five minutes and then added. The bomb containing the sediment sample, $\mathrm{CuO}, \mathrm{NaOH}$ and a stainless steel agitator was loaded, open, into a glove bag (Cheltenham PA $\mathrm{X}-27-27 \mathrm{H}$ ) which was then purged with nitrogen for one hour. After sealing in the glove bag, the bomb was placed in an oven. This was heated from room temperature to $170^{\circ} \mathrm{C}$ and held at $170^{\circ} \mathrm{C}$ for three hours. The bomb was shaken manually once every hour for 30 seconds. After three hours, 
the bomb was cooled under running water. Upon opening, $100 \mu \mathrm{l}$ of ethyl vanillin solution $(10 \mathrm{mg}$ in $10 \mathrm{ml}$ diethyl ether) was added as an internal standard. The contents of the bomb were then transferred with $8 \% \mathrm{NaOH} / \mathrm{H}_{2} \mathrm{O}$ washings to a centrifuge tube. The residual sediments were separated at $2000 \mathrm{rpm}(600 \mathrm{~g})$ for 10 minutes using a 'Universal 16R Hettich Zentrigugen' centrifuge. The residue was rinsed twice with $20 \mathrm{ml} \mathrm{NaOH} / \mathrm{H}_{2} \mathrm{O}$ and centrifuged as before. Supernatants were combined and acidified to $\mathrm{pH} 1$ with approximately $30 \mathrm{~cm}^{3} 6 \mathrm{~N} \mathrm{HCl}$. The product was extracted three times with diethyl ether $\left(3 \times 10 \mathrm{~cm}^{3}\right)$, the extracts combined, dried with anhydrous $\mathrm{Na}_{2} \mathrm{SO}_{4}$, filtered through 'Whatman GF/F' filters, and then rotary-evaporated to dryness. The product was transferred with diethyl ether into a pre-weighed vial, and a 'Pierce Model 18780 Reacti-
Vap TM' evaporating unit was used to remove the ether by nitrogen blow down. The sample was kept in a refrigerator under nitrogen for subsequent analysis. The total extracted material was weighed prior to the derivatisation procedure described below.

Each sample was derivatised by reaction with $100 \mu \mathrm{l}$ Bis(trimethylsilyl)trifluoroacetamide/ trimethylchlorosilane $(10: 1)$ at $40^{\circ} \mathrm{C}$ for two hours (Readman et al., 1986) using a 'Techne Dri-Block DB.3D' heater. The derivatised samples were blown down with nitrogen in a fume hood. Samples were dissolved in $100 \mu \mathrm{l}$ dry toluene for analysis by gas chromatography.

Figure 4 shows the procedures involved in the determination of lignin components from the sediment samples, and also from the dissolved and particulate matter

\section{Sediment samples}

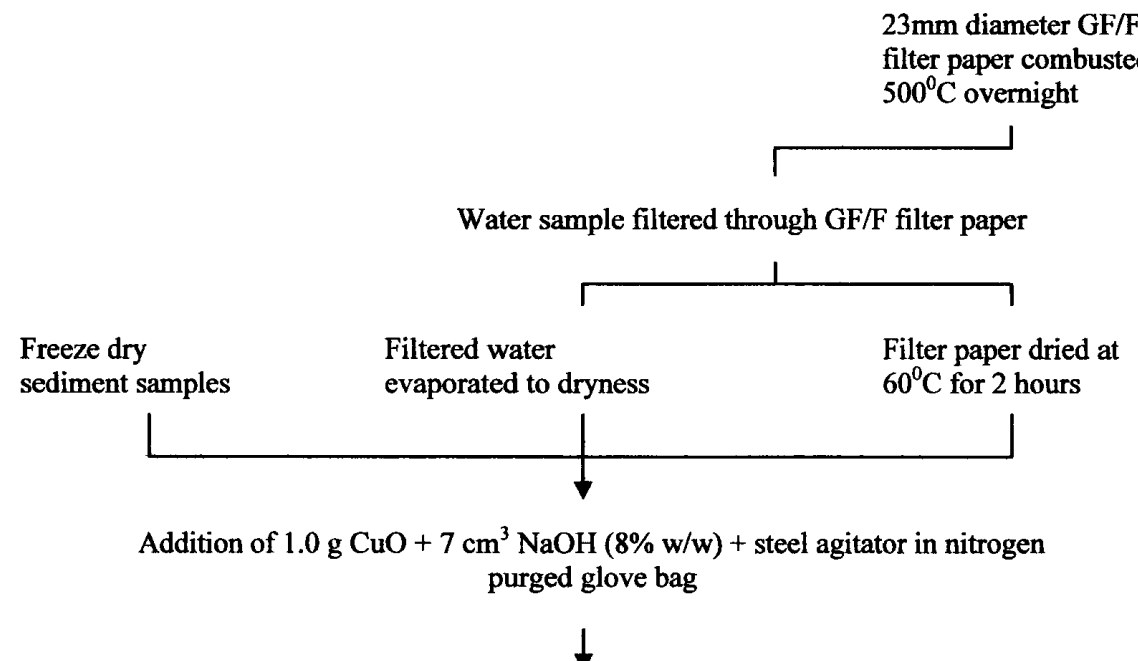

Heated from room temperature to $170^{\circ} \mathrm{C}$ for 3 hours

Addition of ethvl vanillin as internal standard

Centrifugation, acidification with $6 \mathrm{~N} \mathrm{HCl}$ and extraction with diethyl ether

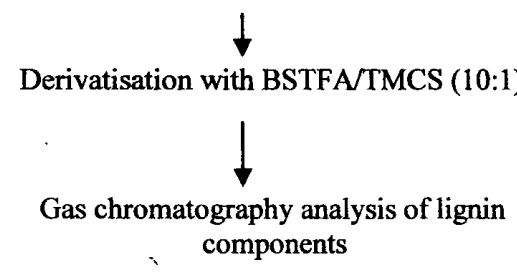

\section{Lignin from
particulate matter \\ Lignin from
particulate matter}

$23 \mathrm{~mm}$ diameter $\mathrm{GF} / \mathrm{F}$

filter paper combusted at 
from water samples. Individual oxidation products were quantified by using gas chromatography (Perkin-Elmer 8410 fitted with a $30 \mathrm{~m} \times 0.25 \mathrm{~mm}$ i.d. ZB-1 Zebron column supplied by Phenomenex). The injector was used in split mode (100:1). The FID detector output was collected and integrated using Star Chromatograph software. Identification of the oxidation products was completed using a TRACE MS (Thermo Quest, Finnigan) gas chromatograph-mass spectrometer system fitted with a $30 \mathrm{~m} \times$ $0.25 \mathrm{~mm}$ i.d. RTX-5MS, Restek Corp. column. Results were integrated and identified using Xcalibur software.

\section{OXYGEN UPTAKE FROM INTACT CORES}

Oxygen uptake rates were determined from the decrease in dissolved oxygen in the overlying water of incubated intact sediment cores ( $6 \mathrm{~cm}$ diameter), as described by Parkes and Buckingham (1986). Each core was sealed with a stirrer head incorporating a sampling port. Cores were incubated at $9.5^{\circ} \mathrm{C}$ for $18-23 \mathrm{~h}$. The enclosed water was then sampled and analysed for oxygen by Winkler titration. The uptake rate was calculated assuming a linear uptake (zero order with respect to oxygen). Final oxygen concentrations were not less than $60 \%$ of the starting concentration.

\section{LOSS ON IGNITION}

Losses on ignition at two temperatures, $250^{\circ} \mathrm{C}$ and $500^{\circ} \mathrm{C}$ for 16 hours, were determined for freeze-dried sediment samples $(0.5 \mathrm{~g})$.

The RP value, as defined by Kristensen (1990), was calculated to characterize the organic matter further. The $\mathrm{RP}$ index is given by the equation: $\mathrm{RP}=\mathrm{PII} /(\mathrm{PI}+\mathrm{PII})$, where $\mathrm{PI}$ is the weight loss in the temperature range $20-250^{\circ} \mathrm{C}$ and PII is the weight loss for the range $250-500^{\circ} \mathrm{C}$ (' $\mathrm{R}$ ' stands for ratio and ' $\mathrm{P}$ ' for peak).

\section{Results and discussion}

\section{LIGNIN ANALYSIS}

The 11 standards and 1 internal standard used for the quantification of lignin are shown in Fig. 5 (all standards from SIGMA). Figure 6 shows the 11 lignin standards and ethyl vanillin as detected by gas chromatography-mass spectrometry (GC-MS). Figure 7 shows the standards as detected by the gas chromatography-flame ionisation detector (GC-FID). The average retention times for all the 11 lignin oxidation products and the internal standard are given in Table 2.

Figures 8 and 9 show chromatograms of lignin oxidation products from sites RE6 and LC1 respectively. The S/V and
Table 2. The retention times (average \pm one standard deviation, $\mathrm{n}=5$ ) for all 12 lignin oxidation products in a standard mixture, as detected by the GC-FID

\begin{tabular}{lrr}
\hline Lignin & $\begin{array}{l}\text { Retention time } \\
\text { of individual } \\
\text { oxidation product } \\
\text { (mins) }\end{array}$ & $\begin{array}{l}\text { Standard } \\
\text { error (\%) }\end{array}$ \\
\hline 1. p-hydroxybenzaldehyde & $4.944 \pm 0.012$ & 0.53 \\
2. p-hydroxyacetophenone & $6.513 \pm 0.012$ & 0.56 \\
3. Vanillin & $7.610 \pm 0.010$ & 0.47 \\
4. Ethyl vanillin & $8.844 \pm 0.009$ & 0.39 \\
5. Acetovanillone & $9.327 \pm 0.008$ & 0.38 \\
6. p-hydroxybenzoic acid & $9.960 \pm 0.008$ & 0.36 \\
7. Syringaldehyde & $10.919 \pm 0.008$ & 0.37 \\
8. Acetosyringone & $12.503 \pm 0.013$ & 0.60 \\
9. Vanillic acid & $12.696 \pm 0.007$ & 0.32 \\
10. Syringic acid & $15.282 \pm 0.008$ & 0.36 \\
11. p-coumaric acid & $16.110 \pm 0.008$ & 0.36 \\
12. Ferulic acid & $18.895 \pm 0.009$ & 0.39 \\
\hline
\end{tabular}

$\mathrm{C} / \mathrm{V}$ ratios, used to characterise sources of terrigenous organic matter (Goni et al., 1998) were calculated. For station RE6, the $\mathrm{S} / \mathrm{V}$ ratio (0.185) indicates that gymnosperm tissues predominate, whilst the $\mathrm{C} / \mathrm{V}$ ratio (0.869) suggests a predominance of non-woody material. The results for station $\mathrm{LC} 1$ are similar, i.e. the $\mathrm{S} / \mathrm{V}$ ratio $(0.258)$ shows that gymnosperm-derived materials dominate and the $\mathrm{C} / \mathrm{V}$ ratio (0.929) signifies the prevalence of non-woody plants. This is the situation along both loch transects.

\section{OXYGEN UPTAKE RATE}

An estimate of the total amount of biodegradable material in sediments can be made by measuring the oxygen uptake rates of intact sediment cores from their overlying water, and the results of such preliminary measurements are shown in Fig. 10. Each solid data point represents the result of one core incubation. Variation between cores is to be expected since the actual rates measured will depend at least in part on the amount of biological irrigation. This, in turn, will depend on the random capture of bio-irrigating animals within the core tubes. In Loch Etive there are two major freshwater inputs, the Rivers Etive and Awe, which will have the greatest impact on stations RE2 and RE6 respectively, and intact sediment samples from these have the highest uptake rates. Station Camas Nathais is well away from the impact of material from the loch and this has the 
LIGNIN OXIDATION PRODUCTS

SiLyLATED DERIVATIVES

p-Hydroxybenzaldehyde<smiles>O=Cc1ccc(O)cc1</smiles>

p-Hydroxacetophenone
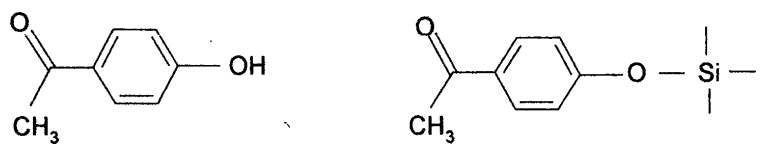

Vanillin (4-hydroxy-3-methoxybenzaldehyde)<smiles>COc1cc(C=O)ccc1O</smiles>

Ethyl vanillin (3-ethoxy-4-hydroxybenzaldehyde)<smiles>CCOc1cc(C=O)ccc1C</smiles>

$\mathrm{OH}$<smiles>COc1cc(C=O)ccc1O[Si](C)(C)C</smiles>

Acetovanillone (3-methoxy-4-hydroxyacetophenone)<smiles>COc1cc(C(C)=O)ccc1O</smiles><smiles>COc1cc(C(C)=O)ccc1O[Si](C)(C)C</smiles>

p-Hydroxybenzoic acid<smiles>O=C(O)c1ccc(O)cc1</smiles><smiles>C[Si](C)(C)OC(=O)c1ccc(O[Si](C)(C)C)cc1</smiles>

LIGNIN OXIDATION PRODUCTS

Silylated DERIVATIVES

Syringaldehyde (4-hydroxy-3,5-dimethoxybenzaldehyde)<smiles>COc1cc(C=O)cc(OC)c1O</smiles><smiles>COc1cc(C=O)cc(OC)c1O[Si](C)(C)C</smiles>

Acetosyringone (3,5-dimethoxy-4-hydroxy-acetophone)<smiles>COc1cc(C(C)=O)cc(OC)c1O</smiles><smiles>COc1cc(C(C)=O)cc(OC)c1O[Si](C)(C)C</smiles>

Syringic acid (3,5-dimethoxy-4-Hydroxybenzoic acid)<smiles>COc1cc(C(=O)O[Si](C)(C)C)cc(O[Si](C)(C)Oc2c(OC)cc(C(=O)O)cc2OC)c1OC</smiles>

p-Coumaric acid (4-hydroxcinnamic acid)<smiles>C[Si](C)(C)OC(=O)/C=C/c1ccc(O[Si](C)(C)C)cc1</smiles>

Ferulic acid (4-hydroxy-3-methoxycinnamic acid)<smiles>COc1cc(/C=C/C(=O)O)ccc1O</smiles><smiles>COc1cc(/C=C/C(=O)O[Si](C)(C)C)ccc1O[Si](C)(C)C</smiles>

Vanillic acid (benzoic acid, 4-hydroxy-3-methoxy benzoic acid)<smiles>COc1cc(C(=O)O)ccc1O</smiles><smiles>COc1cc(C(=O)O[Si](C)(C)C)ccc1O[Si](C)(C)C</smiles>

Fig. 5. Lignin oxidation products and their trimethylsilated cupric oxide oxidation products 


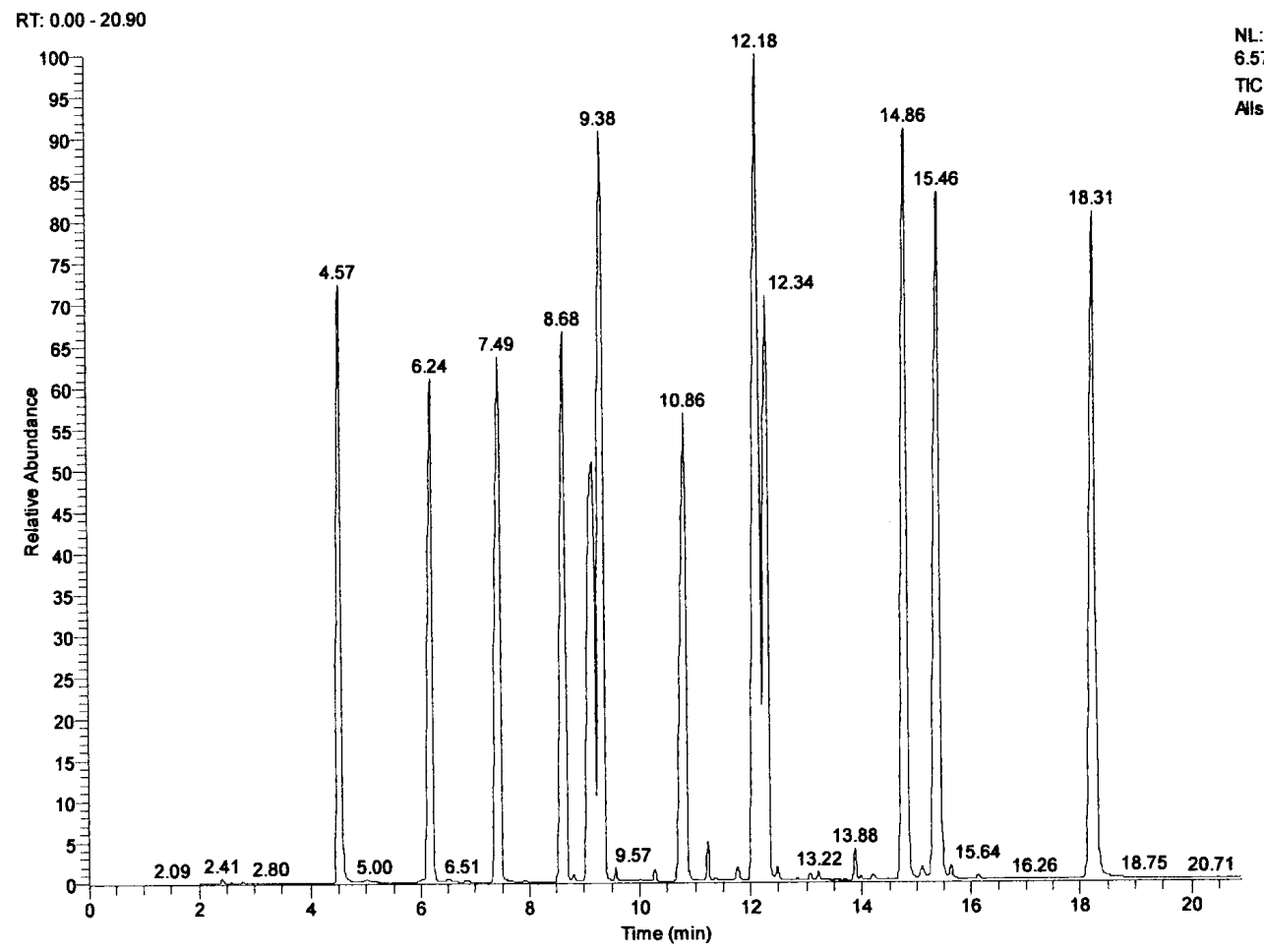

$6.57 E 7$

TIC MS
Alsid

Retention time : Lignin standard

4.57: p-hydroxybenzaldehyde 6.24: p-hydroxyacetophenone 7.49: vanillin

8.68: ethyl vanillin (i.s)

9.21: acetovanillone

9.38: p-hydroxybenzoic acid 10.35: syringaldehyde 12.18: vanillic acid 12.34: acetosyringone 14.86: syringic acid 15.46: p-courmaic acid 18.31: ferulic acid

Fig. 6. Twelve lignin standards $\left(1 \mu \mathrm{g} \mu \mathrm{l}^{-1}\right)$ as detected by gas chromatogrphy-mass spectrometry (GC-MS).

For GC conditions see Readman et al., 1986)

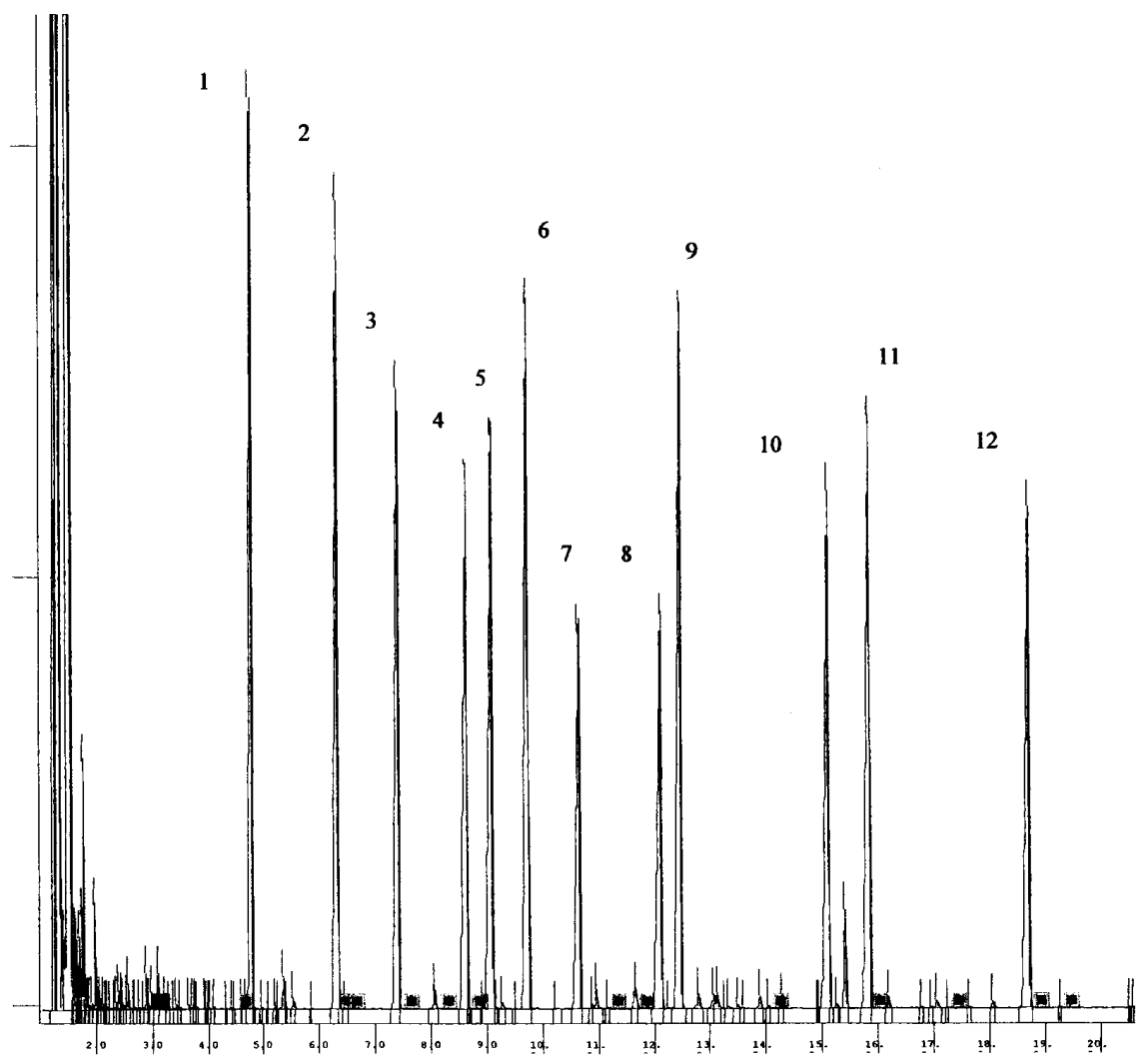

Number : Lignin standard

1. p-hydroxybenzaldehyde

2. p-hydroxyacetophenone

3. vanillin

4. ethyl vanillin

5. acetovanillone

6. p-hydroxybenzoic acid

7. syringaldehyde

8. acetosyringone

9. vanillic acid

10. syringic acid

11. p-courmaic acid

12. ferulic acid

Fig. 7. Lignin standards $\left(1 \mu g \mu l^{-1}\right)$ detected by the GC-FID 


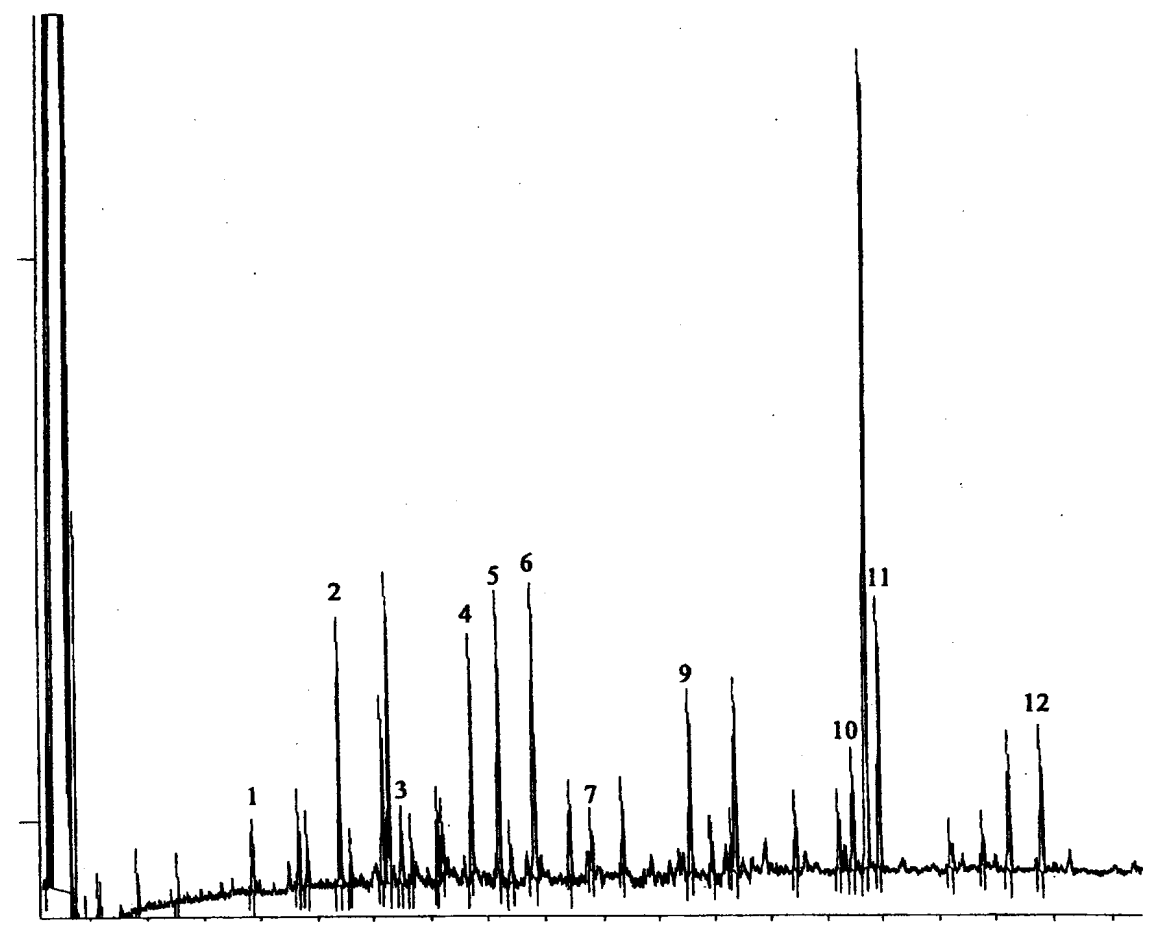

Fig. 8. Chromatogram showng Me Si-lignin-derived phenols detected in surface sediment samples from RE6. Peaks for each lignin phenol are: (1) p-hydroxybenzaldehyde; (2) p-hydroxyacetophenone; (3) vanillin; (4) ethyl vanillin; (5) acetovanillone; (6)p-hydroxybenzoic acid; (7) syringaldehyde; (9) vanillic acid; (10) syringic acid; (11) p-courmaic acid; (12) ferulic acid. Only acetosyringone (peak number 8) is not detected.

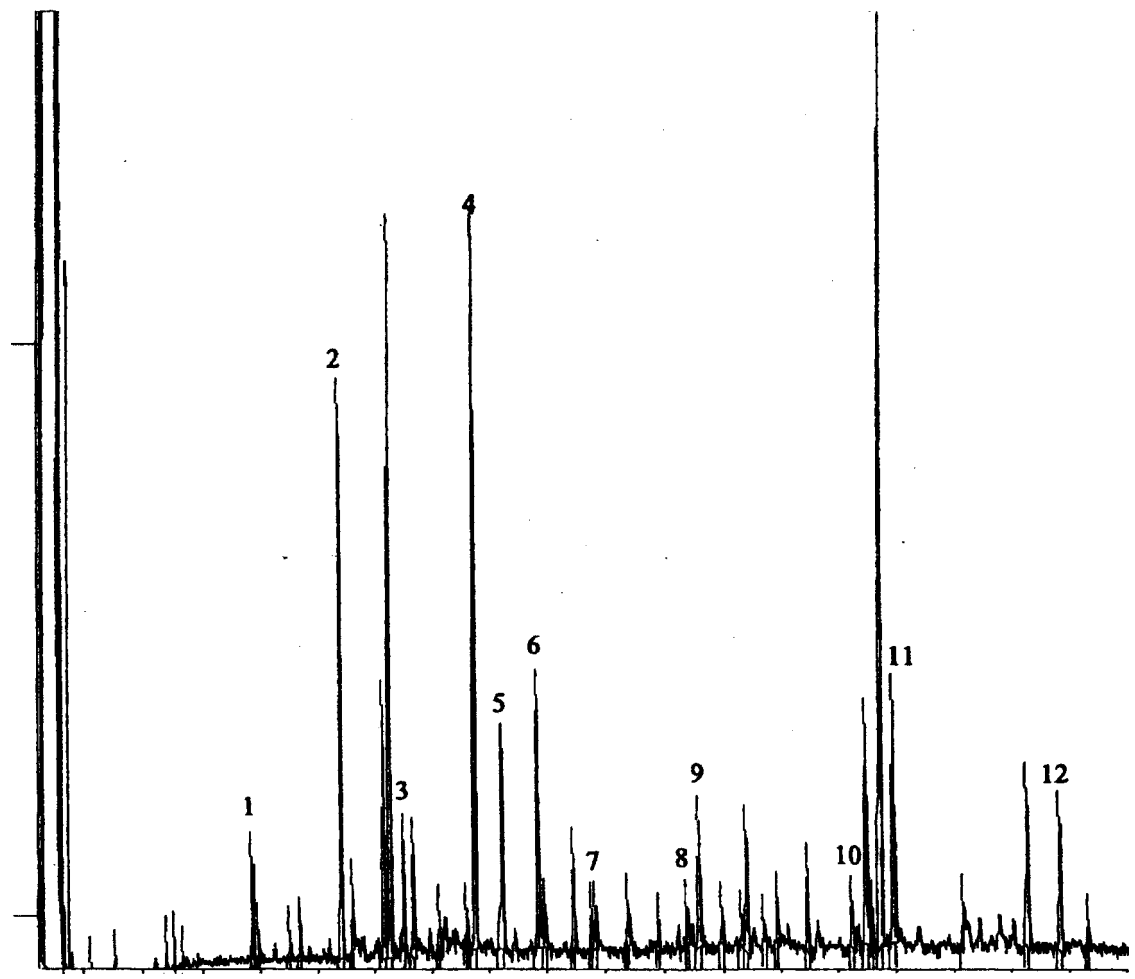

Fig. 9. Chromatogram showng Me Si-lignin-derived phenols detected in surface sediment samples from LC1. Peaks for each lignin phenol are: (1) p-hydroxybenzaldehyde; (2) p-hydroxyacetophenone; (3) vanillin; (4) ethyl vanillin; (5) acetovanillone; (6)p-hydroxybenzoic acid;

(7) syringaldehyde; (8)acetosyringone; (9) vanillic acid; (10) syringic acid; (11) p-courmaic acid; (12) ferulic acid. 


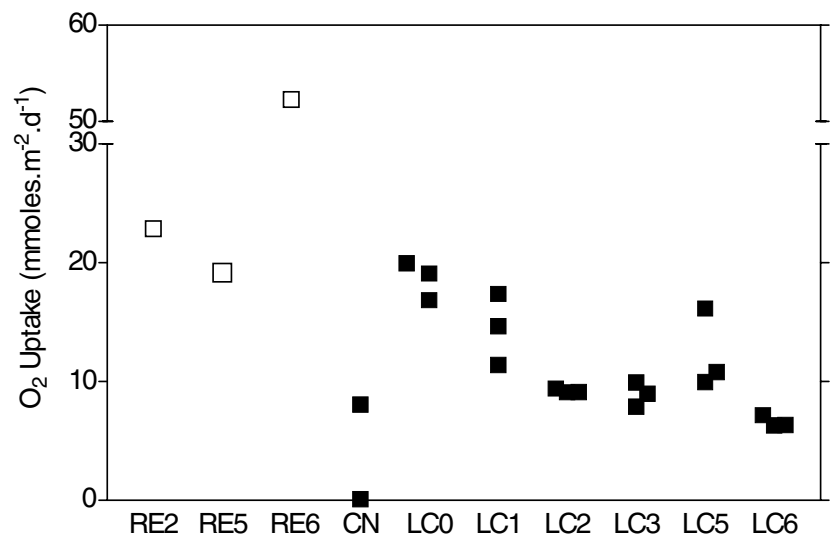

Fig. 10. Oxygen uptake by sediment in intact cores as a function of station position in Lochs Etive and Creran. Open symbols, average data from Overnell (1996), solid symbols, this work. Each solid symbol represents a single incubation. Two or three symbols at each location represent duplicate or triplicate cores.

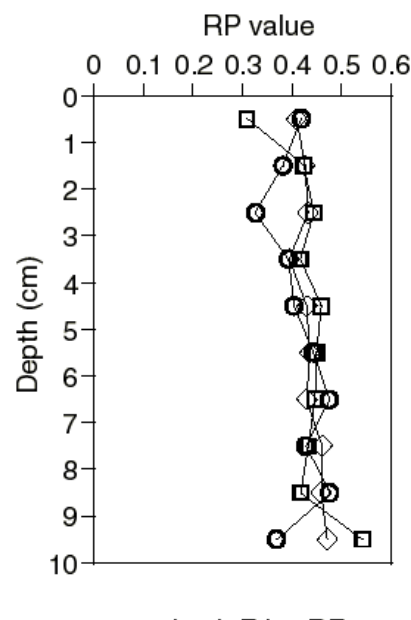

Loch Etive RE6

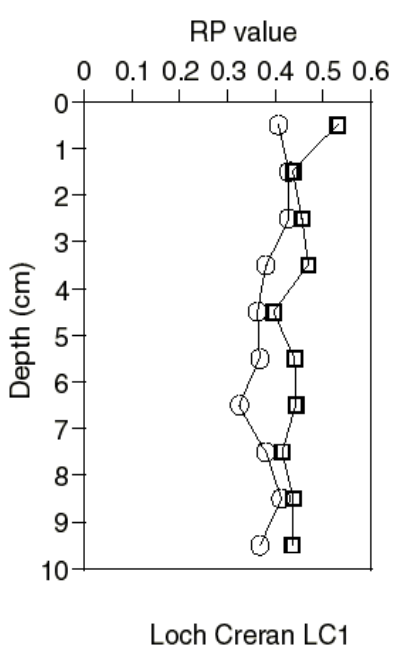

Fig. 11. Depth profiles of RP values for samples from replicate sediment cores from Lochs Etive and Creran lowest oxygen uptake rate. The maximum uptake rate in Loch Creran is at the LC0, the head of the loch and there is a decline in uptake rates down the loch to station LC6 just outside the loch. These data suggest that terrigenous materials from the rivers have a major influence on the input of biodegradable particulate organic material into the sea loch sediments.

The oxygen uptake rates need to be compared with estimates of terrigenous input to be derived from lignin analysis. In addition, oxygen uptake rates need to be compared with other parameters of biodegradability such as $\mathrm{C} / \mathrm{P}$ and $\mathrm{C} / \mathrm{N}$ ratios and $\mathrm{RP}$ values of the sediment as determined by thermal gravimetry (Kristensen, 1990).

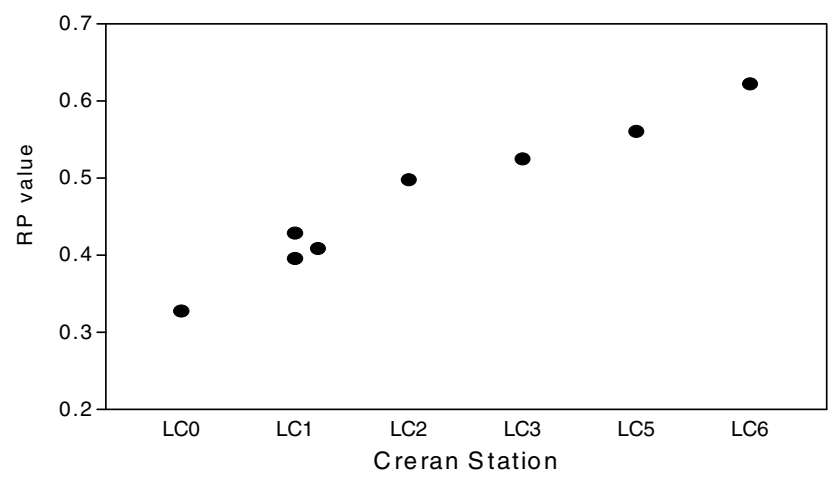

Fig. 12. RP value as a function of station position (top $1-2 \mathrm{~cm}$ fraction) in Loch Creran along transect from the head to the sea (LCO to LC6)

\section{LOSS ON IGNITION AND RP VALUES}

The RP index provides a tool for the characterisation of organic matter. RP values in the range 0.2 to 0.3 are characteristic of aliphatic carbohydrates and lipids. Values in the range 0.5 to 0.7 are characteristic of proteins and polyphenolic compounds, i.e humates. (Kristensen, 1990).

Figure 11 shows the depth profiles of RP values for samples from replicate sediment cores from Lochs Etive and Creran. It can be seen that there is very little systematic change down to $10 \mathrm{~cm}$. In this context, it was found that the RP values in a sediment profile in the marine lagoon Fællesstrand, Denmark, showed an increase from 0.43 to 0.51 over the depth interval $0-0.5 \mathrm{~cm}$ to $6-8 \mathrm{~cm}$ (Kristensen, 1990), which presumably reflects the formation of increasingly recalcitrant organic material as the organic material is slowly degraded. Lochs Etive and Creran do not show this change. Sedimentation rates are expected to be high in these sea loch locations and thus a possible reason for the lack of an increase of RP with depth in these samples is that the time available for degradation was small compared with the Fællesstrand site. Recent sedimentation rates for the upper basin of Loch Etive, determined by measuring ${ }^{210} \mathrm{~Pb}$, have been reported as $0.06 \mathrm{~g} \mathrm{~cm}^{-2} \mathrm{yr}^{-1}$ (Howe et al., 2001).

The smooth increase in RP value seen in the top $1-2 \mathrm{~cm}$ fraction (Fig. 12) for the transect from the head of Loch Creran to the sea indicates that the organic component is becoming increasingly recalcitrant as the amount of degradation increases. A possible explanation is that particulate organic material in the sediment is being slowly transported down the loch in the water column and in the process is undergoing progressive degradation. In future work the RP index needs to be correlated with the $\mathrm{C}: \mathrm{N}$ ratio to determine the origin of the organic matter. 


\section{Conclusions}

Preliminary results indicate that, along transects from the head of Lochs Creran and Etive (West Coast of Scotland) to the sea, it is the input of particulate terrigenous organic carbon (particularly sediments containing non-woody gymnosperm tissue) that determines oxygen uptake rates. The projected long-term outcome of this research is a dataset that will allow correlation of the terrigenous organic carbon content in sediments with measures of the biogeochemical reactivity of those sediments. With some independent measurements of sedimentation rates, the results will permit estimates to be made of the local rate of burial of terrigenous organic carbon and the proportion of marine organic carbon that is being removed from the biosphere, i.e. locked up in the sediments.

\section{References}

Bader, R.G., 1956. The lignin fraction of marine sediments. DeepSea Research, 4, 15-22.

Bianchi, T.S. and Argyrou, M.E., 1997. Temporal and spatial dynamics of particulate organic carbon in the Lake Pontchartrain Estuary, southeast Lousinia, U.S.A. Estuar. Coast. Shelf Sci., 45, 557-569.

Cain, R.B., 1980. The uptake and catabolism of lignin-related aromatic compounds and their regulation in micro-organisms. In: Lignin biodegradation: microbiology, chemistry, and potential application, T.K. Kirk, T. Higuchi and H-M. Chang, (Eds.). CRC Press, 1, 21-60.

Chang, H-M., Chen, C-L. and Kirk, T. K., 1980. The chemistry of lignin degradation by white-rot fungi. In: Lignin biodegradation: microbiology, chemistry, and potential application, T.K. Kirk, T. Higuchi and H-M. Chang, (Eds.). CRC Press, 1, 215-230.

Christman, R. F. and Oglesby, R. T., 1971. Microbiological degradation and the formation of humus. In: Lignins occurrence, formation, structure and reactions, K.V. Sarkanen and C.H. Ludwig (Eds.). Wiley-Interscience.

Craib, J.S., 1965. A sampler for taking short undisturbed marine cores. J. Cons. Perm. Intern. Expl. Mer., 30, 34-39.

Crawford, R.L., Robinson, L.E. and Cheh, A.M., $1980 .{ }^{14} \mathrm{C}-$ labelled lignins as substrates for the study of lignin biodegradation and transformation. In: Lignin biodegradation: microbiology, chemistry, and potential application, T.K. Kirk, T. Higuchi and H-M. Chang, (Eds.). CRC Press, 1, 61--76.

Edwards, A. and Sharples, F., 1991. Scottish sea lochs. A catalogue. SMBA special publications no. 134, 110pp.

Eisma, D., Bernard, P., Boon, J.J., Van Grieken, R., Kalf, J. and Mook, W.C., 1985. Loss of particulate organic matter in estuaries as exemplified by the Ems and Gironde estuaries. In: Transport of carbon and minerals in major world rivers, E.T. Degens, S. Kempe and R. Herrera (Eds.). 58, 397-412.

Ertel, J.R. and Hedges, J.I., 1984. The lignin component of humic substances: Distribution among soil and sedimentary humic, fulvic, and base-insoluble fractions. Geochim. Cosmochim. Acta, 48, 2065-2074.

Goni, M.A. and Hedges, J.I., 1990. Cutin-derived $\mathrm{CuO}$ reaction products from purified cuticles and tree leaves. Geochim. Cosmochim. Acta, 54, 3065-3072.
Goni, M.A. and Hedges, J.I., 1992. Lignin dimers: Structures, distribution, and potential geochemical applications. Geochim. Cosmochim.Acta, 56, 4025-4043.

Goni, M.A. and Hedges, J.I., 1995. Sources and reactivities of marine-derived organic matter in coastal sediments as determined by alkaline $\mathrm{CuO}$ oxidation. Geochim. Cosmochim. Acta, 59, 2965-2981.

Goni, M.A., Ruttenberg, K.C. and Eglinton, T.I., 1998. A reassessment of the sources and importance of land-derived organic matter in surface sediments from the Gulf of Mexico. Geochimica et Cosmochim.Acta, 62, 3055-3075.

Goring, D.A.I., 1971. Polymer properties of lignin and lignin derivatives. In: Lignin occurrence, formation, structure and reactions, K.V. Sarkanen and C.H. Ludwig (Eds,). Wiley Interscience, 695-767.

Gough, M.A., Mantoura, R.F.C. and Preston, M., 1993. Terrestrial plant biopolymer in marine sediments. Geochim. Cosmochim. Acta, 57, 945-964.

Haider, K. and Trojanowski, J., 1980. A comparison of the degradation of 14C-labeled DHP and corn stalk lignins by mocro- and macrofungi and bacteria. In: Lignin biodegradation: microbiology, chemistry, and potential application, T.K. Kirk, T. Higuchi and H-M. Chang, (Eds.). CRC Press, 1, 111-134.

Hedges, J.I. and Ertel, J.R., 1982. Characterization of lignin by gas capillary chromatography of cupric oxide oxidation products. Analyt. Chem., 54, 174-178.

Higuchi, T., 1980. Lignin structure and morphological distribution in plant cell walls. In: Lignin biodegradation: microbiology, chemistry, and potential application, T.K. Kirk, T. Higuchi and H-M. Chang, (Eds.). CRC Press, 1, 1-19.

Howe, J.A., Overnell, J., Inall, M.E. and Wilby, D., 2001. Sidescan sonar image of a glacially-overdeepened sea loch, upper Loch Etive, Argyll. Scottish J. Geol., 37, 3-10.

Jørgensen, B.B., 1982. Mineralization of organic matter in the sea bed- the role of sulphate reduction. Nature, 296, 643-645.

Kirk, T. K., Higuchi, T. and Chang, H-M., 1980. Lignin biodegradation: microbiology, chemistry, and potential applications, Vol. 1, CRC Press.

Kristensen, E., 1990. Characterization of biogenic organic matter by stepwise thermogravimetry (STG). Biogeochemistry, 9, 135159.

Libes, S.M., 1992. An introduction to marine biogeochemistry. Wiley, Chichester, UK. 414.

Lyons, W. and Gaudette, H.E., 1979. Sulphate reduction and the nature of organic matter in estuarine sediments. Org. Geochem., 1, 151-155.

Martin, J.P. and Haider, K., 1980. Microbial degradation and stabilization of 14C-labeled lignins, phenols, and phenolic polymers in relation to soil humus formation. In: Lignin biodegradation: microbiology, chemistry, and potential application, T.K. Kirk, T. Higuchi and H-M. Chang, (Eds.). CRC Press, 1, 77-100.

Moran, M.A., Pomeroy, L.R., Sheppard, E.S., Atkinson, L.P. and Hodson, R.E., 1991. Distribution of terrestrially derived dissolved organic matter on the southeastern U.S. continental shelf. Limnol. Oceanog., 36, 1134-1149.

Opsahl, S. and Benner, R., 1993. Decomposition of senescent blades of the seagrass Halodule wrightii in a subtropical lagoon. Mari. Ecol.Prog. Ser., 94, 191-205.

Opsahl, S. and Benner, R., 1995. Early diagenesis of vascular plant tissues: Lignin and cutin decomposition and biogeochemical implications. Geochim. Cosmochim. Acta, 59, 4889-4904.

Overnell, J., Harvey, S.M. and Parkes, R.J., 1996. A biogeochemical comparison of sea loch sediments. Manganese and iron contents, sulphate reduction and oxygen uptake rate, Oceanologica Acta, 19, 41-55. 
Parkes, R.J. and Buckingham, W.J., 1986. The flow of organic carbon through aerobic respiration and sulphate-reduction in inshore marine sediments. In: Perspectives on microbial ecology, F. Megusar and G. Gantar (Eds.). 617--624.

Raymond, P.A. and Bauer, J.E., 2001. Riverine export of aged terrestrial organic matter to the North Atlantic Ocean. Nature, 409, 497-500.

Readman, J.W., Mantoura, R.F.C., Llewellyn, C.A., Preston, M.R. and Reeves, A.D., 1986. The use of pollutant and biogenic markers as source discriminants of organic inputs to estuarine sediments. Int. J. Environ. Anal. Chem, 27, 29-54.

Reeves, A.D. and Preston, M.R., 1989. The composition of lignin in estuarine suspended particulates and the distribution of particulate lignin in estuaries as determined by capillary gas chromatography of cupric oxide oxidation products. Estuar. Coast. Shelf Sci., 29, 583-599.
Reeves, A.D. and Preston, M.R., 1991. A study of the composition and distribution of lignin in resuspended and permanently suspended particles in the River Tamar Estuary, Estuar. Coast. Shelf Sci., 32, 11-25.

Sarkanen, K.V. and Ludwig, C.H., 1971. Definition and nomenclature. Lignin occurrence, formation, structure and reactions. Wiley-Interscience.

Watts, L., 1997. Physical and biogeochemical processes in sealochs. Ocean Challenge, 7, 36-42.

Young, L.Y. and Frazer, A.C., 1987. The fate of lignin and ligninderived compounds in anaerobic environments. Geomicrobiol. J., 5, 261-293. 